\title{
Founding Clones, Inbreeding, Coancestry, and Status Number of Modern Apple Cultivars
}

\author{
Dominique A.M. Noiton \\ The Horticulture and Food Research Institute of New Zealand Ltd, Havelock North Research Center, \\ Havelock North, New Zealand \\ Peter A. Alspach \\ The Horticulture and Food Research Institute of New Zealand Ltd, Riwaka Research Center, Motueka, \\ New Zealand
}

Additional index words. breeding, genetic diversity, Malus $\times$ domestica

\begin{abstract}
Pedigrees of apple (Malus $\times$ domestica Borkh.) cultivars were used to study worldwide genetic diversity among clones used in modern apple breeding. The most frequent founding clones were 'Cox's Orange Pippin', 'Golden Delicious', 'Red Delicious', 'Jonathan', and 'McIntosh'. Coefficients of coancestry between 50 mainstream cultivars and these clones averaged $0.03,0.12,0.07,0.06$, and 0.02 , respectively, but they were frequently as high as 0.25 with certain pairings. Among a group of 27 cultivars carrying the $V f$ gene for scab resistance, coefficients of coancestry with the five founding clones were of the same order. Although few of the cultivars sampled were substantially inbred, inbreeding could reach serious levels in their future offspring if current breeding practices are continued. The status effective number was 8 for the mainstream group and 7 for the $V f$-carrier clones. This indicates clearly that apple breeders are operating with a population of greatly reduced genetic diversity. Careful consideration of pedigrees and increased size of the genetic base are needed in future apple breeding strategies.
\end{abstract}

The domestic apple (Malus $\times$ domestica), one of the world's most ancient and most widely cultivated temperate fruit, may have originated in western Asia from natural hybridization between several species including M. sylvestris Mill., M. sieversii Ldb., and M. baccata (L.) Borkh (Roach, 1985). Twenty-five species and more than 7000 cultivars have been reported in apple; however, despite this vast genetic diversity, modern commercial apple production is dominated by only a few cultivars (Way et al., 1990). This trend toward genetic uniformity in commercial apple orchards is further accentuated by the release of additional mutants of popular cultivars (Brooks and Olmo, 1991, 1994).

Most current commercial apple cultivars have been identified as chance seedlings, but these are slowly being replaced by new selections developed by private breeders or by public research agencies. Unfortunately, financial investment in apple breeding is generally decreasing (Way et al., 1990), and many breeding programs are restricted to commercial cultivar production by crossing well-known parents. Few resources are generally put into long-term population improvement. Consequently, most apple breeders are working within a population of a limited genetic base, which is likely to handicap future genetic improvement and the progress of the apple industry.

During the last 30 years, breeding objectives have mainly focused on meeting aesthetic standards established by supermarkets, but eating quality and disease resistance are now receiving greater priority. The apple breeding programs for resistance to scab (Venturia inaequalis Cke.) have mostly concentrated on the $V f$ gene from $M$. floribunda Sieb. clone 821. All cultivars carrying the $V f$ gene originated from a cross between two selections of $M$.

Received for publication 23 Oct. 1995. Accepted for publication 14Feb. 1996. This study was supported by the New Zealand Foundation for Research and Technology. We are grateful to Tony Shelbourne and Luis Gea from the New Zealand Forest Research Institute for sharing their knowledge on the status effective number. We also thank Mark McNeilage, Ron Beatson, and Alan Seal from HortResearch and Tony Shelbourne for editing the manuscript. The cost of publishing this paper was defrayed in part by the payment of page charges. Under postal regulations, this paper therefore must be hereby marked advertisement solely to indicate this fact. floribunda $821 \times$ 'Rome Beauty'. Since 1970, more than 38 cultivars carrying the $V f$ gene have been released commercially (Crosby et al., 1992).

This study attempts to measure genetic diversity presently use in apple breeding throughout the world. Pedigrees available in the literature were used to study the genetic contribution of five major founding clones to a sample of 77 modern apple cultivars. Coefficients of inbreeding (Malécot, 1948) and coancestry (Cruden, 1949) and status effective number (Lindgren et al., 1995) were calculated for the 77 cultivars as indicators of genetic diversity.

\section{Materials and Methods}

Pedigrees of 439 apple cultivars (total of 377) and breeding selections from around the world were collected from available literature (Brooks and Olmo, 1972, 1975, 1978, 1984, 1991, 1994; de Coster, 1986; Cripps et al., 1993; Dayton et al., 1977; Fischer and Fischer, 1993a, 1993b; Korban et al., 1990; Le Lezec and Babin, 1992; Sadamori et al., 1973; Sansavini, 1993; Smith, 1971; Tamba et al., 1992; Wang, 1990; Williams et al., 1967, 1975, 1984; Yamada et al., 1980). From this database, 77 cultivars of known parentage released since 1970 were sampled to represent a range of countries of origin (Table 1). They were classified into two groups represented by 50 mainstream cultivars and by $27 \mathrm{Vf}$ carrier cultivars. The degree of relationship of these 77 clones with the five frequent founding clones, 'McIntosh', 'Golden Delicious', 'Jonathan', 'Cox's Orange Pippin', and 'Red Delicious' was investigated by calculating the individual coefficient of coancestry of each of these clones with the 50 mainstream cultivars and the $27 \mathrm{Vf}$-carrier cultivars. Inbreeding coefficients were calculated for the 77 cultivars themselves, being the same as the coefficient of coancestry of their two parents. Coefficients of coancestry were also calculated among the 50 mainstream cultivars, among the $27 \mathrm{Vf}$-carrier cultivars, and among the 77 cultivars together. This formed the base for calculating the status effective number of these populations.

Inbreeding and coancestry. Inbreeding coefficient of an indi- 
Table 1. Reported parentage, country of origin, and year of commercial release of 77 modern apple cultivars.

\begin{tabular}{|c|c|c|c|}
\hline Cultivar & Reported parentage & Origin & Year \\
\hline \multicolumn{4}{|c|}{ Mainstream group } \\
\hline Akane & Jonathan $\mathrm{x}$ Worcester Pearmain & Japan & 1970 \\
\hline Akita Gold & Golden Delicious x Fuji ${ }^{\mathrm{z}}$ & Japan & 1990 \\
\hline Aori & Toko $^{z}$ x Richared Delicious ${ }^{z}$ & Japan & $>1970$ \\
\hline Arlet & Golden Delicious X Idared ${ }^{z}$ & Switzerland & 1989 \\
\hline Burgundy & Monroe $^{z}$ x (Macoun x Antonovka) & United States & 1974 \\
\hline Chantecler & Golden Delicious x Reinette Clochard & France & 1977 \\
\hline Charden & Golden Delicious x Reinette Clochard & France & 1971 \\
\hline Cloden & Golden Delicious x Reinette Clochard & France & 1977 \\
\hline Delcorf & Jongrimes $x$ Golden Delicious & France & 1974 \\
\hline Delrouval & Delcorf x Akane & France & 1993 \\
\hline Earlidel & Red Delicious x Early McIntosh ${ }^{z}$ & Australia & 1988 \\
\hline Elan & Golden Delicious X James Grieve & Netherlands & 1989 \\
\hline Elstar & Golden Delicious X Ingrid Marie ${ }^{\mathrm{z}}$ & Netherlands & 1972 \\
\hline Empress & Jonamac $^{\mathrm{Z}} \mathrm{x}$ Vista Bella & United States & 1988 \\
\hline Falstaff & James Grieve x Golden Delicious & England & 1989 \\
\hline Feleac & Jonathan open-pollinated & Romania & 1980 \\
\hline Fiesta & Cox’s Orange Pippin x Idared ${ }^{\mathrm{z}}$ & England & 1986 \\
\hline Fushuai & Early McIntosh ${ }^{\mathrm{z}}$ x Golden Delicious & China & 1977 \\
\hline Generos & Frumos de Voinesti x ((Golden Pearmain $\times$ M. kaido $) \times$ Jonathan $)$ & Romania & 1983 \\
\hline Goldsmith & Granny Smith x Golden Delicious & South Africa & 1975 \\
\hline Greensleeves & James Grieve x Golden Delicious & England & 1977 \\
\hline Himekami & Fuji ${ }^{2} \times$ Jonathan & Japan & 1985 \\
\hline Hokuto & Fuji $^{2} \times$ Mutsu $^{2}$ & Japan & $>1970$ \\
\hline Honeycrisp & Macoun $^{2}$ x Honeygold ${ }^{2}$ & United States & 1991 \\
\hline Hongbaoshi & Ralls Janet x Red Delicious & China & 1988 \\
\hline Huaguan & Golden Delicious $x$ Fuji ${ }^{\mathrm{Z}}$ & China & 1988 \\
\hline Huashuai & Fuji $\times$ Starkrimson ${ }^{z}$ & China & 1988 \\
\hline Jinguang & Ralls Janet x Red Delicious & China & 1988 \\
\hline Jubile (Delbart) & Golden Delicious x Lundbytorp & France & $>1970$ \\
\hline Jupiter & Cox's Orange Pippin x Starking Delicious ${ }^{\mathrm{z}}$ & England & 1981 \\
\hline Karmijn & Cox's Orange Pippin x Jonathan & Netherlands & 1971 \\
\hline Kent & Cox's Orange Pippin x Jonathan & England & 1974 \\
\hline Kogetsu & Golden Delicious X Jonathan & Japan & 1981 \\
\hline Korona & (Mother x Red Rome Beauty) x Scotia ${ }^{z}$ & Canada & 1987 \\
\hline Luxiangziao & Jinhong $^{\mathrm{z}} \times\left(\right.$ Ralls Janet $\times$ Starking Delicious $\left.{ }^{\mathrm{v}}\right)$ & China & 1988 \\
\hline Michinoku & Kitakami $^{\mathrm{z}} \times$ Tsugaru $^{\mathrm{z}}$ & Japan & 1981 \\
\hline Pink Lady & Golden Delicious x Lady Williams & Australia & 1986 \\
\hline Predgornoe & London Pippin x Red Delicious & Ukrainia & 1984 \\
\hline Qinguan & Golden Delicious X (Ralls Janet x Red Delicious) & China & 1970 \\
\hline Rubinovoe Duki & Jonathan X Aport Alexander & Ukrainia & 1989 \\
\hline Sansa & Gala $^{z}$ x Akane & Japan & 1989 \\
\hline Scarlet & Akane $x$ Starking Delicious ${ }^{v}$ & Japan & 1984 \\
\hline Senshu & Toko $^{\mathrm{z}} \times \mathrm{Fuji}^{\mathrm{z}}$ & Japan & 1980 \\
\hline Shamrock & McIntosh spur type $x$ Starkspur Golden Delicious ${ }^{u}$ & Canada & 1986 \\
\hline Skifskoe & Golden Delicious x Wagener & Ukrainia & 1984 \\
\hline Summerdel & Red Delicious x Earliblaze & Australia & 1989 \\
\hline Sundowner & Golden Delicious x Lady Williams & Australia & 1979 \\
\hline Suntan & Cox’s Orange Pippin x Court Pendu Plat & England & 1974 \\
\hline Vista Bella & $\left((\right.$ Melba $\times$ Sonora $) \times(($ Williams $\times$ Starr $) \times$ USDA34 $) \times$ Julyred $^{2}$ & United States & 1974 \\
\hline Yanshanhong & Ralls Janet x Richared Delicious ${ }^{v}$ & China & 1989 \\
\hline \multicolumn{4}{|c|}{ Vf-based group } \\
\hline Baujade & $\begin{array}{l}\text { Granny Smith x (Reinette du Mans X (Golden Delicious X } \\
(\text { Golden Delicious X F2 26829-2-2 }) \text { ) }\end{array}$ & & \\
\hline Britegold & Sandel $^{z}$ x (Platt Melba x (Jonathan x F2 26829-2-2ª) & Canada & 1980 \\
\hline \multirow[t]{2}{*}{ Dayton } & $\left(\left(\right.\right.$ Melba $^{z} \times($ Wealthy $\times$ Starr $\left.)\right) \times\left(\right.$ Red Rome Beauty ${ }^{y} \times$ Melba $\left.\left.^{z}\right)\right) \times$ & & \\
\hline & $(($ Jonathan x F2 26829-2-2 $) \times(($ Melba $\times($ Wealthy $\times$ Starr $)) \times$ & United Stater & 1987 \\
\hline Delorina & Grifer x Florina & France & 1993 \\
\hline Enterprise & McIntosh X $\left(\right.$ Starking Delicious $^{v}$ x (Golden Delicious X F2 26829-2-2 $\left.{ }^{z}\right)$ ) sib. & United Sates & 1994 \\
\hline
\end{tabular}


Table 1. Continued.

\begin{tabular}{|c|c|c|c|}
\hline Cultivar & Reported parentage & Origin & Year \\
\hline Florina & Jonathan X (Starking Delicious ${ }^{v}$ X (Golden Delicious X F2 26829-2-2²)) & France & 1977 \\
\hline Freedom & $\left(\right.$ Macoun $^{z}$ X Antonovka $) \times($ Golden Delicious x F2 26829-2-2 $)$ & United States & 1983 \\
\hline Goldrush & $\begin{array}{l}\text { Golden Delicious x (Winesap open-pollinated x }\left(\text { Melrose }^{z} \text { x }\right. \\
(\text { Golden Delicious X F2 26829-2-2 }) \text { )) }\end{array}$ & United States & 1994 \\
\hline Jolana & Spartan x PRI 370/15 & Czechoslovakia & 1985 \\
\hline Jonafree & $(($ Golden Delicious x F2 26829-2-2 $) \times$ Jonathan $) \times\left(\right.$ Gallia Beauty ${ }^{y}$ x Red Spy $\left.{ }^{w}\right)$ & United States & 1979 \\
\hline Liberty & PRI 54-12t x Macoun ${ }^{z}$ & United States & 1979 \\
\hline McShay & McIntosh x (Starking Delicious ${ }^{\mathrm{v}}$ x (Golden Delicious x F2 26829-2-2z) & United States & 1981 \\
\hline Moira & McIntosh x (Jonathan x F2 26829-2-2 $)$ & Canada & 1978 \\
\hline Novamac & McIntosh x (((Melba ${ }^{z} \times($ Wealthy $\times$ Starr $\left.)\right) \times\left(\right.$ Red Rome Beauty $\left.\left.{ }^{\mathrm{y}} \times \mathrm{Melba}^{\mathrm{z}}\right)\right)$ & & \\
\hline & X (Jonathan X F2 26829-2-2ª) & Canada & 1978 \\
\hline Pionier & (Verzisoare $\mathrm{x}$ Jonathan $) \mathrm{x}$ Prima & Romania & 1982 \\
\hline Priam & Jonathan X (Golden Delicious x F2 26829-2-2 & France/USA & 1974 \\
\hline Prima & $\begin{array}{l}\text { (Golden Delicious X F2 26829-2-2 }) \times\left(\left(\text { Melba }^{\mathrm{z}} \times(\text { Wealthy } \times \text { Starr })\right)\right. \\
\left.\left.\text { x (Red Rome Beauty }{ }^{\mathrm{y}} \times \text { Melba }^{\mathrm{z}}\right)\right)\end{array}$ & United States & 1970 \\
\hline Priscilla & Starking Delicious ${ }^{v} \times\left(\right.$ McIntosh $\times\left(\right.$ Golden Delicious $\times$ F2 26829-2-2 $\left.\left.{ }^{z}\right)\right)$ & United States & 1972 \\
\hline Redfree & 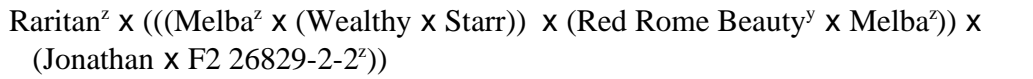 & United States & 1981 \\
\hline Retina & (Cox $\times$ Oldenburg) $\times$ F3 M. floribunda ${ }^{\mathrm{t}}$ & Germany & 1991 \\
\hline Rewena & (Cox x Oldenburg) $\times$ F3 M. floribund $a^{\mathrm{t}}$ & Germany & 1991 \\
\hline Selena & Britemac $^{2} \times$ Prima & Czechoslovakia & 1990 \\
\hline Sir Prize & Tetraploid Golden Delicious X (Golden Delicious x F2 26829-2-2ª) & United States & 1972 \\
\hline Trent & McIntosh x (Jonathan x F2 26829-2-2 $)$ & Canada & 1979 \\
\hline Vandat & Jolana $x$ Lord Lambourne & Czechoslovakia & 1990 \\
\hline Voinea & Frumos de Voinesti x Prima & Romania & 1985 \\
\hline William's Pride & 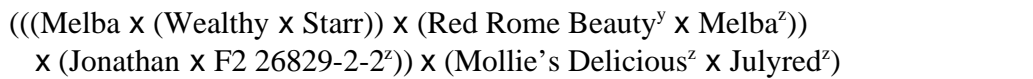 & United States & 1988 \\
\hline
\end{tabular}

z‘Britemac' = 'Melba' x 'Kildare'; 'Early McIntosh' = 'Yellow Transparent' x 'McIntosh'; F2 26829-2-2 = ('Rome Beauty' x M. floribunda 821) x ('Rome Beauty'x M. floribunda 821); 'Fuji’ = 'Ralls Janet' x 'Red Delicious'; 'Gala' = 'Kidd's Orange ('Red Delicious' x 'Cox Orange Pippin') x 'Golden Delicious'; 'Honeygold' = 'Golden Delicious' x 'Haralson'; 'Idared '= 'Jonathan' x 'Wagener'; 'Jonamac' = 'McIntosh' x 'Jonathan'; 'Julyred' = (('Petrel' x 'Early McIntosh') x ('Williams' x 'Starr')); 'Jinhong' = 'Golden Delisious' x 'Hongtaiping'; 'Kitakami' = ('McIntosh' $\mathrm{x}$ 'Worcester Pearmain') x 'Redgold' ('Golden Delicious' $x$ 'Richared Delicious'); 'Macoun'= 'McIntosh' x 'Jersey Black'; 'Melba' = 'McIntosh 'openpollinated ; 'Melrose' = 'Jonathan' x 'Red Delicious'; 'Mollie's Delicious' = ('Golden Delicious' x 'Edgewood') x ('Red Gravenstein' x 'Close'); 'Monroe' = 'Jonathan' x 'Rome Beauty'; 'Mutsu' = 'Golden Delicious' x 'Indo'; 'Raritan' = ('Melba' x 'Sonora') x ('Melba' x ('William’x ‘Starr')); 'Sandel' = 'Red Delicious' $x$ 'Sandow'; 'Scotia' = 'McIntosh' open-pollinated; 'Spartan' = 'McIntoch' x 'Yellow Newton'; 'Tsugaru' = 'Golden Delicious' open-pollinated; 'Toko' = 'Golden Delicious' x 'Indo'.

yMade equivalent to 'Rome Beauty'; 'Gallia Beauty' and 'Red Rome Beauty' = mutations of 'Rome Beauty'.

'Made equivalent to 'Melba'; 'Platt Melba' = mutation of 'Melba'.

wMade equivalent to 'Northern Spy'; 'Red Spy' = mutation of 'Northern Spy'.

'Made equivalent to 'Red Delicious'; 'Starking Delicious' = mutation of 'Red Delicious'; 'Starkrimson' = mutation of 'Starking Delicious';'Richared Delicious' = mutation of 'Red Delicious'.

'Made equivalent to 'Golden Delicious'; 'Starkspur Golden Delicious' = mutation of Golden Delicious'.

t'Incomplete parentage.

vidual was defined by Malécot (1948) as the probability that its allelic pairs were identical by descent. The inbreeding coefficient of an individual depends on the amount of common ancestry of its two parents. The degree of relationship by descent of the two parents is their coefficient of coancestry, $\mathrm{f}$, which is identical with the inbreeding coefficient, $\mathrm{F}$, of their progeny. Inbreeding coefficient was computed using an algorithm developed by Alspach (1976), which is very similar to that of Cruden (1949).

All parents were treated as diploid, and parents of unknown origin were assumed to be unrelated and noninbred. Apples are mostly self-incompatible, and it was assumed that cultivars without known pedigree originated from outcrossed open-pollination, underestimating possible inbreeding. All mutants were regarded as the same as the original cultivar (for example 'Jonared' was listed as 'Jonathan'). Since only few genes are expected to be different between such mutants and the original, this simplification can lead to minor overestimation of inbreeding coefficients. Al- lelic contributions from both parents were assumed to be equal and unaltered by breeders' selection. As it is uncertain whether apple breeders would select for or against homozygosity, the effect of this assumption on the inbreeding coefficient estimate is unknown.

Status effective number. The status effective number of a breeding population (Lindgren et al., 1995) is defined as the number of unrelated and noninbred genotypes in an ideal panmictic population that would produce progeny with the same average coefficient of inbreeding as the progeny of the genotypes of a panmictic breeding population. Self-pollination and free mating with relatives is assumed in the panmictic breeding population. Status effective number, which can be compared with the actual census number of a population, measures the genetic diversity of that population. It can be derived for any population of known pedigree through calculating the matrix of coancestries. It can never be higher than the census number, and it generally declines with time. Status number is calculated as Ns $=0.5 / \mathrm{f}$, where Ns is 
Table 2. Inbreeding coefficients and coancestry coefficients with 'Cox's Orange Pippin', 'Red Delicious', Golden Delicious', 'Jonathan', and 'MacIntosh' of 77 modern apple cultivars.

\begin{tabular}{|c|c|c|c|c|c|c|}
\hline \multirow[b]{2}{*}{ Cultivar } & \multirow[b]{2}{*}{$\begin{array}{l}\text { Inbreeding } \\
\text { coefficients }\end{array}$} & \multicolumn{5}{|c|}{ Coefficient of coancestry with } \\
\hline & & $\begin{array}{l}\text { Cox's Orange } \\
\text { Pippin } \\
\end{array}$ & $\begin{array}{c}\text { Red } \\
\text { Delicious }\end{array}$ & $\begin{array}{c}\text { Golden } \\
\text { Delicious }\end{array}$ & Jonathan & MacIntosh \\
\hline \multicolumn{7}{|c|}{ Mainstream group } \\
\hline Akane & 0.000 & 0.000 & 0.000 & 0.000 & 0.250 & 0.000 \\
\hline Akita Gold & 0.000 & 0.000 & 0.125 & 0.250 & 0.000 & 0.000 \\
\hline Arlet & 0.000 & 0.000 & 0.000 & 0.250 & 0.125 & 0.000 \\
\hline Burgundy & 0.000 & 0.000 & 0.000 & 0.000 & 0.125 & 0.063 \\
\hline Chantecler & 0.000 & 0.000 & 0.000 & 0.250 & 0.000 & 0.000 \\
\hline Charden & 0.000 & 0.000 & 0.000 & 0.250 & 0.000 & 0.000 \\
\hline Cloden & 0.000 & 0.000 & 0.000 & 0.250 & 0.000 & 0.000 \\
\hline Delcorf & 0.000 & 0.000 & 0.000 & 0.250 & 0.000 & 0.000 \\
\hline Delrouval & 0.000 & 0.000 & 0.000 & 0.125 & 0.125 & 0.000 \\
\hline Earlidel & 0.000 & 0.000 & 0.250 & 0.000 & 0.000 & 0.125 \\
\hline Elan & 0.000 & 0.000 & 0.000 & 0.250 & 0.000 & 0.000 \\
\hline Elstar $^{2}$ & 0.000 & 0.125 & 0.000 & 0.250 & 0.000 & 0.000 \\
\hline Empress & 0.063 & 0.000 & 0.000 & 0.000 & 0.125 & 0.188 \\
\hline Estivale & 0.000 & 0.000 & 0.250 & 0.125 & 0.000 & 0.000 \\
\hline Falstaff & 0.000 & 0.000 & 0.000 & 0.250 & 0.000 & 0.000 \\
\hline Feleac & 0.000 & 0.000 & 0.000 & 0.000 & 0.250 & 0.000 \\
\hline Fiesta & 0.000 & 0.250 & 0.000 & 0.000 & 0.125 & 0.000 \\
\hline Fushuai & 0.000 & 0.000 & 0.000 & 0.250 & 0.000 & 0.125 \\
\hline Generos & 0.000 & 0.000 & 0.000 & 0.000 & 0.125 & 0.000 \\
\hline Goldsmith & 0.000 & 0.000 & 0.000 & 0.250 & 0.000 & 0.000 \\
\hline Greensleeves & 0.000 & 0.000 & 0.000 & 0.250 & 0.000 & 0.000 \\
\hline Himekami & 0.000 & 0.000 & 0.125 & 0.000 & 0.250 & 0.000 \\
\hline Hokuto & 0.000 & 0.000 & 0.125 & 0.125 & 0.000 & 0.000 \\
\hline Honeycrisp & 0.000 & 0.000 & 0.000 & 0.125 & 0.000 & 0.125 \\
\hline Hongbaoshi & 0.000 & 0.000 & 0.250 & 0.000 & 0.000 & 0.000 \\
\hline Huaguang & 0.000 & 0.000 & 0.125 & 0.250 & 0.000 & 0.000 \\
\hline Huashuai & 0.250 & 0.000 & 0.375 & 0.000 & 0.000 & 0.000 \\
\hline Jinguang & 0.000 & 0.000 & 0.250 & 0.000 & 0.000 & 0.000 \\
\hline Jubilee & 0.000 & 0.000 & 0.000 & 0.250 & 0.000 & 0.000 \\
\hline Jupiter & 0.000 & 0.250 & 0.250 & 0.000 & 0.000 & 0.000 \\
\hline Karmijn & 0.000 & 0.250 & 0.000 & 0.000 & 0.250 & 0.000 \\
\hline Kent & 0.000 & 0.250 & 0.000 & 0.000 & 0.250 & 0.000 \\
\hline Kogetsu & 0.000 & 0.000 & 0.000 & 0.250 & 0.250 & 0.000 \\
\hline Korona & 0.000 & 0.000 & 0.000 & 0.000 & 0.000 & 0.125 \\
\hline Luxiangziao & 0.000 & 0.000 & 0.125 & 0.125 & 0.000 & 0.000 \\
\hline Michinojku & 0.063 & 0.000 & 0.063 & 0.188 & 0.000 & 0.063 \\
\hline Pink Lady & 0.000 & 0.000 & 0.000 & 0.250 & 0.000 & 0.000 \\
\hline Predgornoe & 0.000 & 0.000 & 0.250 & 0.000 & 0.000 & 0.000 \\
\hline Qinguan & 0.000 & 0.000 & 0.125 & 0.250 & 0.000 & 0.000 \\
\hline Rubinovoe & 0.000 & 0.000 & 0.000 & 0.000 & 0.250 & 0.000 \\
\hline Sansa & 0.000 & 0.063 & 0.063 & 0.125 & 0.125 & 0.000 \\
\hline Scarlet & 0.000 & 0.000 & 0.250 & 0.000 & 0.125 & 0.000 \\
\hline Senshu & 0.000 & 0.000 & 0.125 & 0.125 & 0.000 & 0.000 \\
\hline Shamrock & 0.000 & 0.000 & 0.000 & 0.250 & 0.000 & 0.250 \\
\hline Skifskoe & 0.000 & 0.000 & 0.000 & 0.250 & 0.000 & 0.000 \\
\hline Summerdel & 0.000 & 0.000 & 0.250 & 0.000 & 0.000 & 0.000 \\
\hline Sundowner & 0.000 & 0.000 & 0.000 & 0.250 & 0.000 & 0.000 \\
\hline Suntan & 0.000 & 0.250 & 0.000 & 0.000 & 0.000 & 0.000 \\
\hline Vista Bella & 0.109 & 0.000 & 0.000 & 0.000 & 0.000 & 0.125 \\
\hline Yanshanhong & 0.000 & 0.000 & 0.250 & 0.000 & 0.000 & 0.000 \\
\hline Mean & 0.010 & 0.029 & 0.073 & 0.121 & 0.055 & 0.024 \\
\hline \multicolumn{7}{|c|}{ Vf-carrier group } \\
\hline Baujade & 0.000 & 0.000 & 0.000 & 0.094 & 0.000 & 0.000 \\
\hline Britegold & 0.000 & 0.000 & 0.125 & 0.000 & 0.063 & 0.063 \\
\hline Dayton & 0.297 & 0.000 & 0.000 & 0.000 & 0.063 & 0.094 \\
\hline Delorina & 0.000 & 0.000 & 0.063 & 0.031 & 0.125 & 0.000 \\
\hline
\end{tabular}




\begin{tabular}{|c|c|c|c|c|c|c|}
\hline \multirow[b]{2}{*}{ Cultivar } & \multirow[b]{2}{*}{$\begin{array}{l}\text { Inbreeding } \\
\text { coefficients }\end{array}$} & \multicolumn{5}{|c|}{ Coefficient of coancestry with } \\
\hline & & $\begin{array}{l}\text { Cox's Orange } \\
\text { Pippin }\end{array}$ & $\begin{array}{c}\text { Red } \\
\text { Delicious }\end{array}$ & $\begin{array}{c}\text { Golden } \\
\text { Delicious }\end{array}$ & Jonathan & MacIntosh \\
\hline Enterprise & 0.250 & 0.000 & 0.125 & 0.063 & 0.000 & 0.250 \\
\hline Florina & 0.000 & 0.000 & 0.125 & 0.063 & 0.250 & 0.000 \\
\hline Freedom & 0.000 & 0.000 & 0.000 & 0.125 & 0.000 & 0.063 \\
\hline Goldrush & 0.063 & 0.000 & 0.031 & 0.281 & 0.031 & 0.000 \\
\hline Jolana $^{y}$ & 0.000 & 0.000 & 0.000 & 0.000 & 0.000 & 0.125 \\
\hline Jonafree & 0.066 & 0.000 & 0.031 & 0.094 & 0.156 & 0.000 \\
\hline Liberty $^{\mathrm{y}}$ & 0.000 & 0.000 & 0.000 & 0.000 & 0.000 & 0.125 \\
\hline McShay & 0.000 & 0.000 & 0.125 & 0.063 & 0.000 & 0.250 \\
\hline Moira & 0.000 & 0.000 & 0.000 & 0.000 & 0.125 & 0.250 \\
\hline Novamac & 0.063 & 0.000 & 0.000 & 0.000 & 0.063 & 0.281 \\
\hline Pionier & 0.000 & 0.000 & 0.000 & 0.063 & 0.125 & 0.031 \\
\hline Priam & 0.000 & 0.000 & 0.000 & 0.125 & 0.250 & 0.000 \\
\hline Prima & 0.031 & 0.000 & 0.000 & 0.125 & 0.000 & 0.063 \\
\hline Priscilla & 0.000 & 0.000 & 0.250 & 0.063 & 0.000 & 0.125 \\
\hline Redfree & 0.000 & 0.000 & 0.000 & 0.000 & 0.063 & 0.031 \\
\hline Retina $^{y}$ & 0.000 & 0.125 & 0.000 & 0.000 & 0.000 & 0.000 \\
\hline Rewera $^{y}$ & 0.000 & 0.125 & 0.000 & 0.000 & 0.000 & 0.000 \\
\hline Selena & 0.063 & 0.000 & 0.000 & 0.063 & 0.000 & 0.094 \\
\hline Sir Prize & 0.250 & 0.000 & 0.000 & 0.375 & 0.000 & 0.000 \\
\hline Trent & 0.000 & 0.000 & 0.000 & 0.000 & 0.125 & 0.250 \\
\hline Vanda $^{y}$ & 0.000 & 0.000 & 0.000 & 0.000 & 0.000 & 0.063 \\
\hline Voinea & 0.000 & 0.000 & 0.000 & 0.063 & 0.000 & 0.031 \\
\hline William's Pride & 0.033 & 0.000 & 0.000 & 0.031 & 0.078 & 0.078 \\
\hline Mean & 0.041 & 0.009 & 0.032 & 0.064 & 0.056 & 0.084 \\
\hline Grand mean & 0.021 & 0.022 & 0.058 & 0.101 & 0.055 & 0.045 \\
\hline
\end{tabular}

z'Ingrid Marie' assumed to derived from 'Cox's Orange Pippin' open pollination.

yIncomplete parentage available.

the status number, and $\mathrm{f}$ is the average coancestry of the population (including selfing).

\section{Results and Discussion}

Founding clones. About $64 \%$ of 439 cultivars and selections studied was found to be descended from only five founding clones: 'McIntosh' (101 cultivars), 'Golden Delicious' (87 cultivars), 'Jonathan' (74 cultivars), 'Cox's Orange Pippin' (59 cultivars), and 'Red Delicious' (56 cultivars). Among these, 96 cultivars had two or more of the five founding clones in their parentage. Other frequent cultivars occurring in pedigrees included 'James Grieve', 'Rome Beauty', and 'Wealthy'.

'McIntosh' was extensively used as a parent in Canada (it is present in pedigrees of 37 of the 65 Canadian cultivars sampled), the United States (34 of 115), and eastern Europe (11 of 41), but rarely occurred in pedigrees from other countries (5 of 159). 'Golden Delicious' was found in the pedigrees of many cultivars from Pacific-Rim countries such as Japan, China, Australia, and New Zealand (26 of 47), from western Europe (18 of 50), and to a lesser extent from the United States (21 of 115). 'Jonathan' was mostly used in breeding programs in western Europe (13 of 50) and in the United States (29 of 115). 'Cox's Orange Pippin' contributed to 30 of the 62 cultivars released from the United Kingdom compared to 15 of the 50 cultivars from western Europe and 10 of the 227 cultivars from all other countries. 'Red Delicious' was frequent in pedigrees of cultivars from Pacific-Rim countries (17 of 47) ) and from the United States (26 of 115).

Of 439 cultivars and selections sampled, $41 \%$ of those released before 1930 was related to at least one of the five main founding clones. This increased to 74\% during 1940-60 and remained at $73 \%$ in recent releases.

These results support Brown's concern (1973) about the trend in excessive use of 'Cox's Orange Pippin', 'Golden Delicious', 'Jonathan', 'Red Delicious', and 'McIntosh' as parents. The problem of restricted number of founding clones in apple breeding is common to many fruit crops, such as raspberry (Dale et al., 1993), blueberry (Hancock and Siefker, 1982), and peach (Scorza et al., 1988). The predominance of only five founding clones in modern apple cultivars may be explained by the lack of information on the breeding value of apple germplasm, which deters breeders from using untested parents. Cultivars such as 'Golden Delicious', 'Red Delicious', 'Jonathan', 'McIntosh', and 'Cox's Orange Pippin' have been reported to be generally valuable parents (Davis et al., 1954; Lantz, 1936). 'Red Delicious' seems to transmit red color, while 'Cox's Orange Pippin' and 'Golden Delicious' are useful to breed yellow and green apples (Brown, 1992; Percival and Proctor, 1994). In addition, mutants of 'Red Delicious', 'McIntosh', and 'Golden Delicious' are used in breeding for compact, spur-type, and dwarf growth habits (Brown, 1992).

Coancestry of apples. The mean coefficients of coancestry (Table 2) of the 77 cultivars included in this study were 0.101 with 'Golden Delicious', 0.058 with 'Red Delicious', 0.055 with 'Jonathan', 0.044 with 'McIntosh', and 0.022 with 'Cox's Orange Pippin'. Coefficients of coancestry ranged between 0 for most pairings to 0.281 for 'GoldRush' with 'Golden Delicious' and 'Novamac' with 'McIntosh'. The high levels of coancestry found 


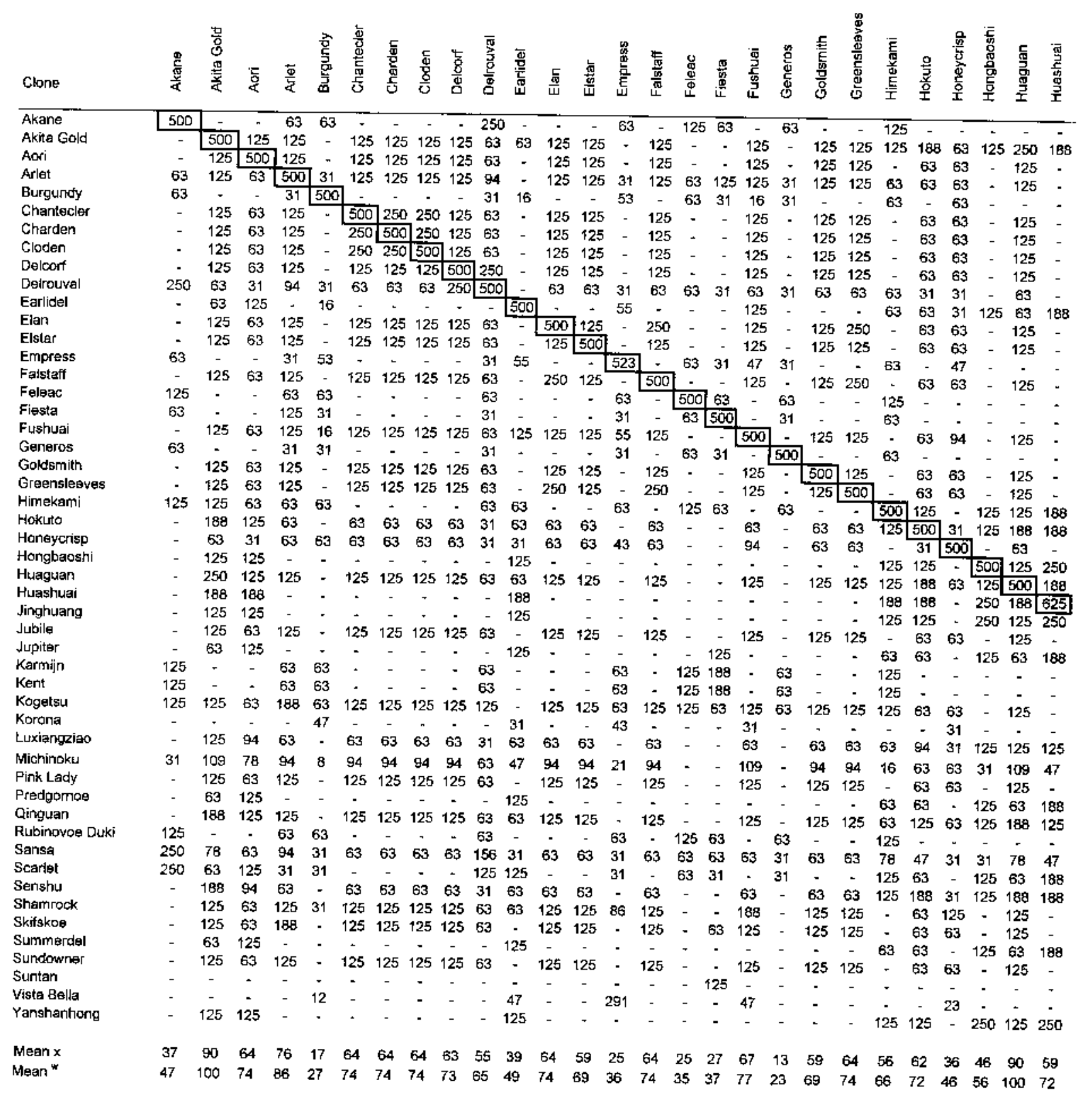

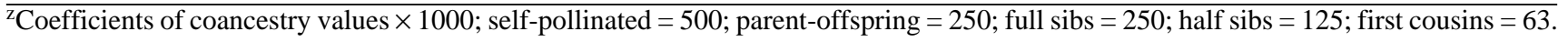
No coancestry of known parents indicated with dashes.

${ }^{x}$ Mean coefficient of coancestry excluding selfing.

${ }^{w}$ Mean coefficient of coancestry including selfing.

between many modern cultivars and 'Golden Delicious', 'Red Delicious', 'Jonathan', 'McIntosh', and 'Cox's Orange Pippin' indicate that further use of the five founding clones or their descendants will increase the risk of inbreeding in future generations.

Coefficients of coancestry among all 77 cultivars are shown in Tables 3, 4, and 5. The mean coancestry within cultivars in the mainstream (Table 3 ) and $V f$-carrier (Table 4) groups was similar (0.051 and 0.050 , respectively). Mean coancestry coefficients ranged from 0.006 to 0.090 in the first group and from 0.017 to 0.088 in the second group. The mean coancestry (Table 5) between the mainstream and the $V f$-carrier group was more than half $(0.032)$ of that found for each group and ranged from 0.009 to 0.092 . Mean coancestry of the 77 selected apple cultivars was comparable with coancestry in plums (0.069 to 0.080) (Byrne, 1989) but was low compared with average coancestry reported in peaches $(0.023$ to $0.208,0.034$ to 0.330 ) (Scorza et al., 1985)..

Coancestry between mainstream cultivars (Table 3 ) was generally higher than coancestry between $V f$-carrier cultivars (Table 4). About 25\% of parental combinations in the first group had coefficients of coancestry $\geq 0.125$ (selfings excluded) against $8 \%$ in the second group. About $5 \%$ of parental combinations between both groups (Table 5) showed coefficients of coancestry $>0.125$. These results indicate that pedigrees should be carefully examined before 


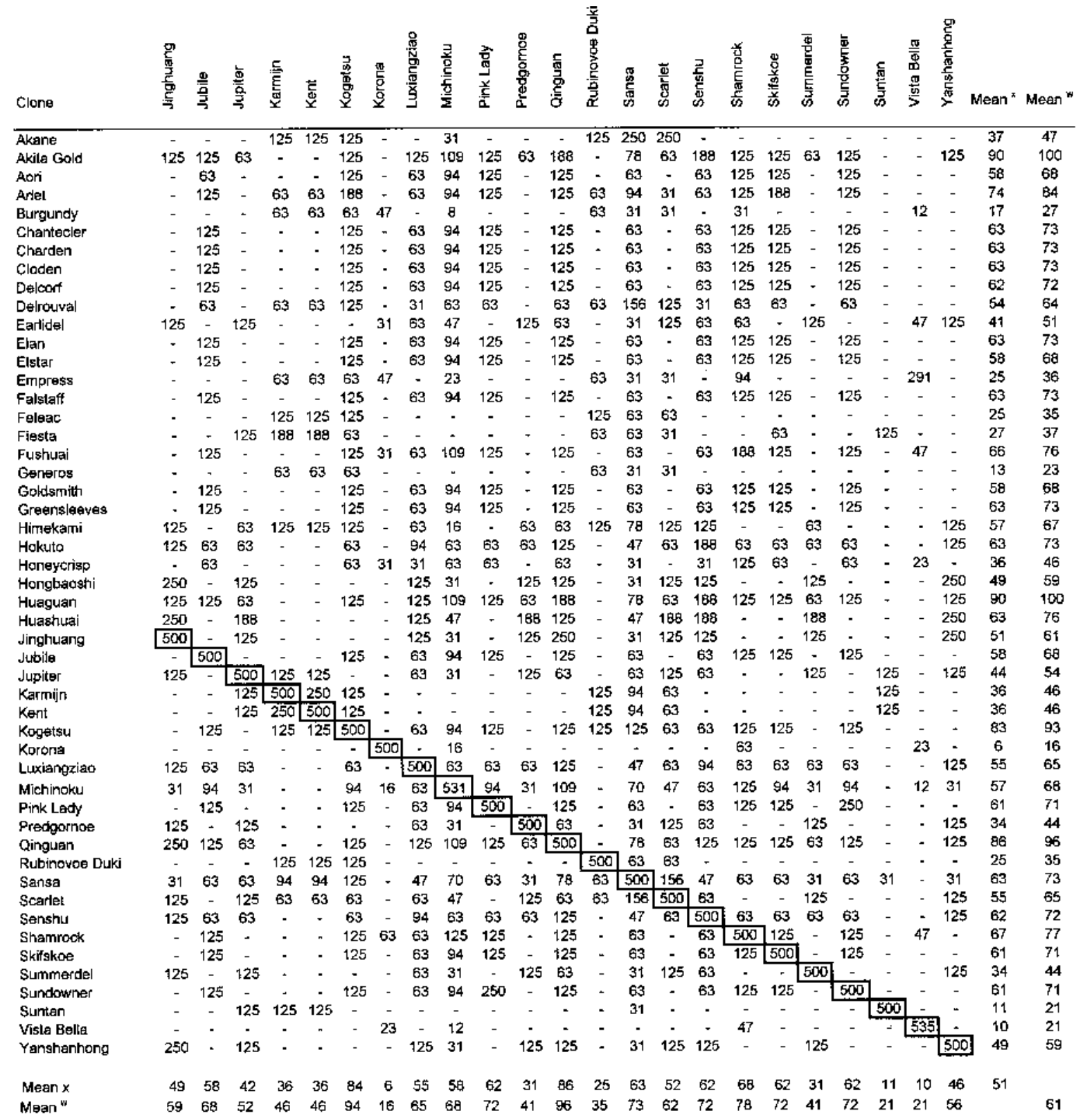

selecting parents. With increasing demands for disease-resistant cultivars, future apple cultivars will not solely derive from intermating individuals within the mainstream group. However, with the high coefficients of coancestry between many individuals from the mainstream and $V f$-carrier groups (Table 5), the latter group provides only a short-term solution. In addition, report of a new race of apple scab virulent to all $V f$ gene cultivars and selections tested (Parisi et al., 1993) reinforces the need for other sources of scab resistance. It is essential in future to introduce new germplasm into breeding programs and combine resistances to several diseases and pests.

Inbreeding coefficients. Among cultivars sampled, $6 \%$ showed an inbreeding coefficient $>0$. Inbreeding coefficients ranged from 0 for most cultivars to 0.297 for 'Dayton'. The inbreeding coefficients of 'Tydeman's Late Orange', 'Sinta', 'Enterprise', 'Howgate Wonder', 'Mellow', and 'Webster' were all 0.250. For the 77 modern cultivars studied, four of the 50 mainstream cultivars and nine of the $27 V f$-carrier cultivars were inbred (Table 2). Mean inbreeding coefficients were 0.01 for cultivars in the mainstream group and 0.04 for cultivars in the $V f$-carrier group. Overall, the inbreeding level in apple is low compared with other fruit crops such as peach (0.26 to 0.35) (Scorza et al., 1988), blueberry (0.13) (Hancock and Siefker, 1982), and raspberry (0.12) (Dale et al., 1993). Mean inbreeding coefficients in apple are similar to those reported in plums (0.02 to 0.05) (Byrne, 1989). However mean coefficients of coancestry of the 77 apple cultivars sampled were 2 to 5 times their mean inbreeding coefficients. Consequently, even if inbreeding in apple is not a problem in this generation, the coancestry level of many future potential parents indicates that problems may arise in the next generation.

Little is known about the effects of inbreeding in apple. It has increased the juvenile period of progenies related to 'Cox's Orange 


\begin{tabular}{|c|c|c|c|c|c|c|c|c|c|c|c|c|c|c|c|c|c|c|c|c|c|c|c|c|c|c|c|c|c|}
\hline Clone & 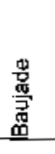 & $\begin{array}{l}\text { 믐 } \\
\text { 苟 } \\
\text { 䓂 }\end{array}$ & $\begin{array}{l}\text { 돔 } \\
\text { 兽 } \\
\end{array}$ & $\begin{array}{l}\frac{\mathrm{w}}{\mathrm{g}} \\
\mathrm{g} \\
\mathrm{g}\end{array}$ & 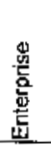 & $\begin{array}{l}\text { 罙 } \\
\frac{\overline{5}}{\mathbf{L}} \\
\end{array}$ & 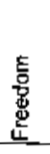 & $\begin{array}{l}\frac{5}{5} \\
\frac{9}{2} \\
\frac{5}{3} \\
0\end{array}$ & 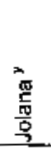 & $\begin{array}{l}\text { 总 } \\
\text { 莺 } \\
\text { 总 } \\
\end{array}$ & 蛋 & 要 & 墨空 & 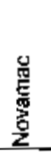 & $\begin{array}{l}\text { 占 } \\
\text { 总 } \\
\underline{0}\end{array}$ & 焉 & 震 & 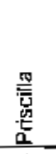 & 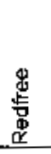 & 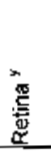 & 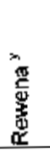 & $\begin{array}{l}\frac{m}{5} \\
\frac{d}{5}\end{array}$ & 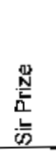 & $\begin{array}{l}\text { 壱 } \\
\text { 站 } \\
\end{array}$ & 要 & $\begin{array}{l}\frac{0}{0} \\
\frac{\mathrm{g}}{5} \\
\end{array}$ & 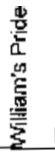 & Mean ${ }^{x}$ & "Mean" \\
\hline Baujade & 500 & 5 & 8 & $B$ & 17 & 17 & 33 & 55 & - & 25 & - & 17 & 10 & 6 & 18 & 33 & 35 & 17 & 6 & 10 & 10 & 18 & 80 & 10 & & 18 & 12 & 17 & 36 \\
\hline Bititeg & 5 & 500 & {$[70$} & 36 & 72 & 72 & 27 & 17 & 16 & 42 & 16 & 72 & 66 & 66 & 43 & $5 \%$ & 55 & 88 & 35 & 20 & 20 & 59 & 20 & 66 & 8 & 27 & 47 & 41 & 60 \\
\hline Dayt & $g$ & 70 & 648 & 23 & 63 & 47 & 43 & 12 & 23 & 43 & 23 & 63 & $\begin{array}{l}09 \\
94\end{array}$ & $\begin{array}{l}00 \\
145\end{array}$ & $\begin{array}{l}40 \\
139\end{array}$ & 63 & 246 & 39 & 98 & 31 & 31 & 170 & 31 & 94 & 12 & 123 & 116 & 68 & 92 \\
\hline Delorina & 8 & 36 & 23 & 500 & 63 & 250 & 18 & 35 & - & 60 & - & 31 & 41 & $\begin{array}{c}140 \\
21\end{array}$ & 41 & 94 & 20 & 40 & 21 & 10 & 10 & 10 & 33 & 41 & - & 10 & 27 & 35 & 53 \\
\hline Enterprise & 17 & 72 & 63 & 65 & 625 & {$[125$} & 66 & 55 & 63 & 41 & 63 & 198 & 145 & 152 & 35 & 63 & 70 & 143 & 27 & 20 & 20 & 66 & 66 & 145 & 31 & 35 & 47 & 70 & 93 \\
\hline Fori & 17 & 72 & 47 & 250 & 725 & $50 \pi$ & 35 & 70 & - & 110 & - & 63 & 82 & 43 & 82 & 188 & 39 & 80 & 43 & 20 & 20 & 20 & 66 & 82 & - & 20 & 55 & 6 & 79 \\
\hline reedom & 33 & 27 & 43 & 18 & 66 & 35 & 500 & $\mathrm{BO}$ & 16 & 53 & 63 & 60 & 70 & $\begin{array}{l}43 \\
59\end{array}$ & 43 & 70 & 86 & 51 & 27 & 43 & 43 & 51 & 133 & 70 & 8 & 43 & 39 & 49 & 68 \\
\hline Bolatrush & 55 & 17 & 12 & 35 & 55 & 70 & 80 & 537 & - & $18 B$ & - & 55 & 18 & 10 & 49 & 109 & 82 & 56 & 10 & 10 & 10 & 41 & 221 & 18 & - & 41 & 20 & 47 & 67 \\
\hline olang & - & 15 & 23 & - & 63 & - & 16 & -7 & 500 & $=$ & 31 & 63 & 63 & 70 & $\begin{array}{l}49 \\
8\end{array}$ & - & 16 & 31 & a & - & - & 23 & 24 & 63 & 250 & $B$ & 16 & 2 & 47 \\
\hline ree & 25 & 42 & 43 & 60 & 41 & 119 & 53 & 188 & & 533 & L & 41 & 88 & 37 & 69 & 145 & 59 & 42 & 37 & 29 & 29 & 29 & 100 & 68 & - & 29 & 48 & & 72 \\
\hline bert & : & 16 & 23 & : & 63 & - & 63 & - & 31 & - & 500 & 63 & 63 & 70 & $B$ & - & 16 & 31 & 8 & & - & 23 & - & 63 & 16 & $\theta$ & 16 & 2 & 40 \\
\hline ICSI & 17 & 72 & 63 & 31 & 186 & 83 & 66 & 55 & 63 & 41 & 63 & 500 & 145 & 152 & 35 & 63 & 70 & 143 & 27 & 20 & 20 & 60 & 66 & 145 & 31 & 35 & 47 & 60 & 85 \\
\hline Ioira & 10 & 66 & 94 & 41 & 145 & 82 & 70 & 18 & 63 & 68 & 63 & 145 & 500 & 180 & 70 & 102 & 78 & 82 & 55 & 39 & 39 & 70 & 39 & 195 & 31 & 39 & 74 & 7 & 91 \\
\hline lowamac & 6 & 66 & 145 & 21 & 152 & 49 & 59 & 10 & 70 & 37 & 70 & 152 & 780 & 531 & 64 & 55 & 98 & 82 & 86 & 23 & 23 & 96 & 23 & 180 & 35 & 49 & 109 & 72 & 91 \\
\hline íoníer & 16 & 43 & 139 & 41 & 35 & 82 & 43 & 49 & 8 & 68 & 8 & 35 & 70 & 64 & 5007 & 102 & 258 & 27 & 49 & 23 & 23 & 145 & 70 & 70 & 4 & 129 & 62 & 6 & 80 \\
\hline rian & 33 & 51 & 63 & 94 & 63 & 188 & 70 & 109 & - & 145 & - & 63 & 102 & $\begin{array}{l}54 \\
55\end{array}$ & $\frac{102}{902}$ & 500] & 78 & 35 & 55 & 39 & 39 & 39 & 133 & 102 & - & 39 & 70 & & 84 \\
\hline rime & 35 & 55 & 246 & 20 & 70 & 39 & 86 & 82 & 15 & 50 & 16 & 70 & 78 & ge & 258 & 78 & 316 & 55 & 66 & 47 & 47 & 269 & 141 & 78 & 8 & 258 & 85 & $\mathrm{~g}$ & 107 \\
\hline riscilla & 17 & $8 \mathrm{~B}$ & 39 & 40 & 143 & 80 & 51 & 56 & 31 & 42 & 31 & 143 & 82 & 82 & 27 & 35 & 55 & 500 & 20 & 20 & 20 & 43 & 66 & 82 & 16 & 27 & 31 & 5 & 6 \\
\hline edfree & 6 & 35 & 98 & 21 & 27 & 43 & 27 & 10 & $B$ & 37 & 8 & 27 & 55 & 86 & 49 & 55 & 56 & 20 & 300 & 23 & 23 & 49 & 23 & 55 & 4 & 33 & 78 & & \\
\hline$a t i n$ & 10 & 20 & 31 & 10 & 20 & 20 & 43 & 10 & $=$ & 20 & $=$ & 20 & 39 & 23 & 23 & 39 & 47 & 20 & 23 & 5007 & 70 & 23 & 39 & 39 & . & 23 & 21 & 2 & 42 \\
\hline Rewh & 10 & 20 & 31 & 10 & 20 & 20 & 43 & 10 & - & 29 & - & 20 & 39 & 23 & 23 & 39 & 47 & 20 & 23 & 70 & 500 & 23 & 39 & 39 & - & 23 & 23 & 2 & 42 \\
\hline Selen & 18 & 59 & 170 & 10 & 66 & 20 & 5.1 & 41 & 23 & 29 & 23 & 60 & 70 & 96 & 145 & 39 & 289 & 43 & 49 & 23 & 23 & 537 & 70 & 70 & 12 & 145 & 68 & & 83 \\
\hline r Plize & 80 & 20 & 31 & 33 & 66 & 66 & 133 & 221 & - & 100 & $=$ & 66 & 39 & 23 & 70 & 133 & 141 & 66 & 27 & 30 & 39 & 70 & 835 & 39 & - & 70 & 47 & & \\
\hline Trent & 10 & 66 & 94 & 41 & 145 & 82 & 70 & 18 & 63 & 68 & 63 & 145 & 195 & 180 & 70 & 102 & 78 & 82 & 55 & 39 & 39 & 70 & 39 & 500 & 31 & 39 & 74 & 72 & 91 \\
\hline Vande & - & 8 & 12 & - & 31 & - & 8 & - & 250 & - & 16 & 31 & 31 & 35 & 4 & 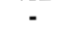 & 8 & 16 & 4 & - & - & 12 & - & 37 & 500 & 4 & 8 & 19 & 37 \\
\hline Voinea & 18 & 27 & 123 & 10 & 35 & 20 & 43 & 41 & 皇 & 29 & 8 & 36 & 39 & 49 & 129 & 39 & $25 B$ & 27 & 33 & 23 & 23 & 145 & 70 & 39 & 4 & 300 & 42 & 49 & 67 \\
\hline William's Pride & 12 & 47 & 116 & 27 & 47 & 55 & 39 & 28 & 16 & 48 & 16 & 47 & 74 & 109 & 62 & 70 & 85 & 31 & 70 & 23 & 23 & 68 & 47 & 74 & 8 & 42 & 515 & $4 \mathrm{E}$ & 67 \\
\hline ean & 17 & 41 & 68 & 35 & 70 & 61 & 49 & 47 & 28 & 52 & 21 & 68 & 72 & 7 & E & 65 & BB & 51 & 36 & 24 & & 64 & 60 & 72 & 19 & 49 & 46 & 50 & \\
\hline ra & 36. & 60 & 92 & 53 & 93 & 39 & 68 & 67 & 47 & 72 & 40 & 85 & 91 & 91 & 80 & $\mathrm{~B} 4$ & 107 & 69 & 54 & 42 & 42 & 83 & 83 & 91 & 37 & 67 & 67 & & 70 \\
\hline
\end{tabular}

${ }^{\mathrm{z} C o e f f i c i e n t s ~ o f ~ c o a n c e s t r y ~ v a l u e s ~} \times 1000$. Self-pollinated $=500$; parent-offspring $=250$; full sibs $=250 ;$ half sibs $=125 ;$ first cousins $=63$. No coancestry of known parents indicated with dashes.

${ }^{\mathrm{y}}$ Cultivars with incomplete parentage.

${ }^{x}$ Mean coefficient of coancestry excluding selfing.

wMean coefficient of coancestry including selfing.

Pippin' and has reduced their vigor and survival rate (Brown, 1973). It can be a useful strategy for the production of commercial cultivars, especially if the relationship between inbreeding coefficients and traits of interest is known. However inbreeding also increases uniformity within progenies which may jeopardize future improvement (Lesley, 1957). The role of inbreeding in apple breeding needs to be studied both for short-term commercial cultivar production and for long-term population improvement.

Status effective number. The status effective numbers were 8.2 for the 50 mainstream cultivars (Table 3), 7.1 for the $27 V f$-carrier cultivars (Table 4), and 10.2 for the 77 cultivars of both groups analyzed together (Table 5). This means that genetic diversity in each of these three groups is reduced to the equivalent of 8,7 , and 10 panmictic-mated, unrelated, and noninbred genotypes, respectively. Such small status effective numbers indicate that breeders are working with a very narrow genetic base.

The status effective number is a useful quantitative measure of the current state of genetic diversity in a breeding population and extends information given by inbreeding and coancestry coefficients (Lindgren et al., 1995). It can be calculated easily for any population from a coancestry matrix and will assist breeders in assessing the germplasm they are using. For example, status effective numbers, calculated from published results, were 2.6 to 4.4 in peach (Scorza et al., 1985) and 6.3 to 7.2 in plums (Byrne, 1989).

Despite the availability of large numbers of modern cultivars and breeding selections from apple breeding programs, worldwide, the actual size of the genetic resources currently used by breeders is small and, in the course of future genetic improvement, may become exhausted. This loss of genetic diversity will result in a preponderance of genes from the main founding clones, while genes from other germplasm will disappear. There is a great need to broaden the genetic base for breeding new apple cultivars. Modified backcross mating design has been used by many breeders to minimize loss of genetic diversity, particularly for the development of scab-resistant apple cultivars carrying the $V f$ gene (Williams et al., 1967, 1975, 1984). However, the genetic base from which these recurrent parents are chosen is still narrow.

One strategy followed in New Zealand since 1989 (Noiton and Shelbourne, 1992) is to use recurrent selection for combining ability to develop an apple breeding population. Such strategy is used by most forest tree breeding programs. The apple breeding population was established from open-pollinated seeds of 500 cultivars collected from clonal repositories throughout the world. This strategy will increase and maintain a high level of diversity for the sustainable improvement of a large number of useful traits.

\section{Literature Cited}

Alspach, P.A. 1976. Computation of inbreeding coefficients from stored pedigree data using Malecot's method. MS thesis, Univ. of York, England.

Brooks, R.M. and H.P. Olmo. 1972. Register of new fruit and nut varieties. 2nd ed. Univ. of California Press, Berkeley.

Brooks, R.M. and H.P. Olmo. 1975. Register of new fruit and nut varieties list 30. HortScience 10:471-478

Brooks, R.M. and H.P. Olmo. 1978. Register of new fruit and nut varieties list 31. HortScience 13:522-532.

Brooks, R.M. and H.P. Olmo. 1984. Register of new fruit and nut varieties list 34. HortScience 19:359-363.

Brooks, R.M. and H.P. Olmo. 1991. Register of new fruit and nut varieties 


\begin{tabular}{|c|c|c|c|c|c|c|c|c|c|c|c|c|c|c|c|c|c|c|c|c|c|c|c|c|c|c|c|c|}
\hline Clone & 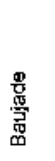 & $\begin{array}{l}\text { 믐 } \\
\text { 莺 } \\
\text { 总 }\end{array}$ & 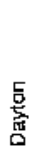 & 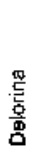 & 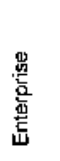 & $\begin{array}{l}\text { 焉 } \\
\text { 总 }\end{array}$ & 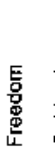 & $\begin{array}{l}\frac{r}{\bar{y}} \\
\frac{\overrightarrow{2}}{\bar{y}} \\
\frac{D}{D}\end{array}$ & $\begin{array}{l}\text { m } \\
\text { 垔 } \\
\text { 吾 }\end{array}$ & 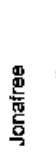 & 带 & $\frac{3}{3}$ & $\frac{g}{\frac{2}{2}}$ & 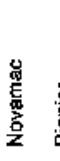 & $\begin{array}{l}\text { 亜 } \\
\text { 要 }\end{array}$ & $\frac{E}{\frac{E}{i}}$ & 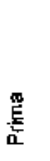 & 总 & 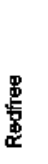 & 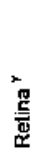 & 喜 & 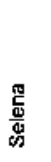 & 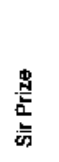 & $\underset{\underline{E}}{\vec{E}}$ & $\begin{array}{l}\text { 要 } \\
\text { 蒠 }\end{array}$ & 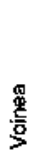 & 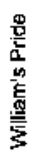 & Mean \\
\hline akane & - & 31 & 31 & 63 & - & 125 & - & 16 & - & 78 & - & - & 63 & 31 & 63 & 125 & & - & 31 & - & $=$ & $=$ & - & 63 & $=$ & $=$ & 39 & 28 \\
\hline Akita Gold & 47 & 31 & - & 31 & 63 & 63 & 63 & 148 & - & 55 & - & $\mathrm{BA}$ & - & - & 31 & 63 & 63 & 94 & - & - & - & Эฺ1 & 168 & - & - & 31 & 96 & 40 \\
\hline Gori & 23 & 63 & - & 39 & 78 & 78 & 31 & 86 & - & 39 & - & 70 & - & $=$ & 16 & 31 & 31 & 141 & - & - & - & 16 & 94 & - & - & 16 & $\mathrm{~g}$ & 32 \\
\hline Arlett & 47 & 16 & 16 & 47 & 31 & 94 & 63 & 148 & - & 86 & r & 31 & 31 & 16 & 63 & 125 & 63 & 31 & 16 & - & $=$ & 31 & 188 & 31 & - & 31 & 35 & 48 \\
\hline gurgundy & $A$ & 31 & 59 & 35 & 39 & 70 & 78 & 12 & 16 & 51 & 83 & 39 & 78 & 65 & 51 & 78 & 39 & 23 & 35 & 20 & 20 & 27 & 16 & $7 \mathrm{~g}$ & 8 & 20 & 43 & 41 \\
\hline Chantecter & 47 & - & - & 16 & 31 & 31 & 63 & 141 & $=$ & 47 & - & 31 & - & - & 39 & 63 & 63 & 31 & $=$ & - & - & 31 & 180 & $=$ & - & 31 & 16 & 32 \\
\hline Chardern & 47 & $=$ & - & 16 & 31 & 31 & 63 & 141 & - & 47 & . & 31 & - & - & 31 & 63 & 63 & 31 & $=$ & - & - & 31 & 100 & - & - & 31 & 16 & 32 \\
\hline Cloden & 47 & - & - & 16 & 31 & 31 & 63 & 141 & - & 47 & - & 31 & - & - & 31 & 63 & 69 & 31 & - & - & - & 31 & 188 & - & - & 31 & 16 & 32 \\
\hline Delcorf & 47 & - & - & 16 & 31 & 31 & 63 & 141 & - & 47 & - & $3+$ & - & - & 31 & 63 & 63 & 31 & - & - & - & 31 & 188 & - & - & 31 & 16 & 32 \\
\hline Delrouval & 23 & 16 & 16 & 39 & 16 & $7 A$ & 31 & 78 & $=$ & 63 & - & 16 & 31 & 96 & 47 & 94 & 31 & 16 & 16 & - & . & 16 & 94 & 31 & - & 16 & 27 & 30 \\
\hline Earlidel & - & 78 & 23 & 31 & 125 & 63 & 16 & 16 & 31 & 16 & 31 & 125 & 63 & 70 & 8 & - & 16 & 156 & 8 & - & . & 23 & - & 63 & 16 & 8 & 27 & 37 \\
\hline Elan & 47 & 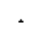 & $=$ & 16 & 31 & 31 & 63 & 141 & - & 47 &. & 31 & - & - & 31 & 63 & 63 & 31 & - & - & $=$ & 31 & 180 & - & - & 31 & 16 & 32 \\
\hline Elstar & 47 & - & 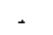 & 16 & 31 & 31 & 63 & 41 & - & 47 & - & 34 & - & - & 31 & 63 & 63 & 31 & . & - & - & 31 & $18 B$ & $=$ & - & 31 & 16 & 32 \\
\hline Emprass & - & 49 & 68 & 31 & 86 & 63 & 21 & 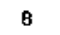 & 43 & 39 & 43 & 86 & 117 & 119 & 49 & 63 & 35 & 43 & 33 & - & - & 51 & . & 117 & 21 & 18 & 82 & 46 \\
\hline Falstaft & 47 & - & - & 16 & 31 & 31 & 63 & 141 & - & 47 & 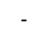 & 31 & . &. & 31 & 63 & 63 & 31 & - & - & - & 31 & 188 & - & 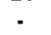 & 31 & 16 & 32 \\
\hline Feleac & - & 31 & 31 & 63 &. & 125 & - & 16 & - & 78 & . & - & 63 & 31 & 63 & 125 & - & - & 31 & . & - & - & - & 63 & - & - & 39 & 28 \\
\hline Fiesta & - & 18 & 16 & 31 & - & 63 & - & $\mathbf{g}$ & - & 39 & - & - & 34 & 16 & 31 & 63 & - & - & 16 & 63 & 63 & - & - & 31 & - & . & 20 & 19 \\
\hline Fushuai & 47 & 1 官 & 23 & 16 & 94 & 31 & 78 & 141 & 31 & 47 & 31 & 94 & 63 & 70 & 39 & 63 & 78 & 69 & 8 & - & - & 55 & $1 \mathrm{BE}$ & 63 & 16 & 39 & 43 & 53 \\
\hline Generos & - & 15 & 16 & 31 & - & 63 & - & 8 & - & 39 & - & - & 31 & 16 & 31 & 63 & - & - & 16 & - & - & - & - & 31 & - & 125 & 20 & 19 \\
\hline Goldsmith & 172 & $=$ & $=$ & 16 & 31 & 31 & 63 & 141 & - & 47 & - & 31 & - & - & 31 & 63 & 63 & 31 & - & - & - & 31 & $1 \mathrm{BB}$ & - & $=$ & 31 & 16 & 36 \\
\hline Greensleaves & 47 & - & - & 18 & 31 & 31 & 63 & 141 & - & 47 & - & 31 & $=$ & $=$ & 31 & 63 & 63 & 31 & - & - & - & 31 & 188 & $=$ & - & 31 & 16 & 32 \\
\hline Himekami & - & 63 & 31 & 78 & 31 & 156 & : & 23 & - & Be & - & 31 & 63 & 31 & 63 & 125 & - & 63 & 31 & - & - & - & - & 63 & - & - & 39 & 36 \\
\hline Hokinto & 23 & 31 & - & 29 & 47 & 47 & 31 & 78 & - & 31 & - & 47 & - & - & 16 & 31 & 31 & 78 & - & - & - & 16 & 94 & - & - & 16 & 8 & 24 \\
\hline Honeyerisp & 23 & 16 & 23 & g & $7 \theta$ & 16 & 94 & 70 & 31 & 23 & 125 & 78 & 63 & 70 & 23 & 31 & 47 & 47 & a & - & - & 39 & 94 & 63 & 16 & 23 & 23 & 42 \\
\hline Hongbaoshi & - & 83 & $=$ & 31 & 63 & 63 & - & 16 & - & 16 & - & 63 & - & - & - & - & - & 125 & - & - & - & - & - & - & $=$ & - & - & 16 \\
\hline Huagutan & 47 & 31 & - & 31 & 63 & 由3 & 63 & 148 & - & 55 & - & 63 & - & * & 31 & 63 & 63 & 94 & - & - & - & 31 & 188 & - & - & 31 & 16 & 40 \\
\hline Huashuai & - & 94 & - & 47 & 94 & 94 & - & 23 & - & 23 & - & 94 & - & - & - & - & - & $18 B$ & $=$ & r & - & - & - & - & - & - & $=$ & 24 \\
\hline Jinghtuan & - & 63 & - & 31 & 63 & 63 & . & 16 & - & 16 & $=$ & 63 & - & $=$ & - & - & - & 125 & - & - & - & - & - & - & - & - & - & 16 \\
\hline Jubilee & 47 & - & $=$ & 16 & 31 & 31 & 69 & 141 & - & 47 & - & 31 & - & - & 31 & 63 & 63 & 31 & - & $=$ & - & 31 & 189 & - & + & 31 & 16 & 32 \\
\hline Jupiter & - & 的 & . & 31 & 63 & 63 & - & 16 & - & 16 & - & 63 & - & - & - & - & - & 125 & - & 63 & B3 & - & - & - & - & - & - & 21 \\
\hline Karmijn & - & 31 & 31 & 63 & - & 125 & - & 16 & - & 78 & - & - & 63 & 31 & 63 & 125 & - & - & 31 & 63 & 63 & - & - & 63 & - & - & 30 & 33 \\
\hline Kent & - & 31 & 31 & 的 & - & 125 & - & 16 & $=$ & 78 & - & - & 63 & 91 & 63 & 125 & - & - & 31 & 63 & 63 & - & - & 63 & - & - & 39 & 33 \\
\hline Kogetsu & 47 & 31 & 31 & 70 & 31 & 156 & 63 & 156 & - & 125 & - & 31 & 63 & 31 & 94 & $18 \mathrm{e}$ & 63 & $\$ 1$ & 31 & $\cdot$ & - & 31 & 188 & 63 & - & 31 & 55 & 60 \\
\hline Korona & 4 & 23 & 55 & 4 & 70 & g. & 31 & 4 & 31 & 12 & 31 & 70 & 78 & 86 & 23 & 16 & 47 & 39 & 23 & 16 & 16 & 39 & 15 & 70 & 16 & 23 & 31 & 33 \\
\hline L џxiangziao & 23 & 31 & $=$ & 23 & 47 & 47 & 31 & 78 & - & 31 & - & 47 & - & - & 16 & 31 & 31 & 79 & - & - & $=$ & $: 6$ & 94 & - & $=$ & 16 & 8 & 24 \\
\hline Micthinoku & 35 & 23 & 12 & 20 & 70 & 39 & 55 & 109 & 16 & 39 & 16 & 70 & 31 & 35 & 27 & 47 & 55 & 70 & 4 & - & - & 35 & 141 & 31 & 8 & 27 & 20 & 38 \\
\hline Pirkk Lady & 47 & . & - & 16 & 31 & 31 & 63 & 141 & $=$ & 47 & - & 31 & - & - & 31 & 53 & 63 & 31 & - & . & - & 31 & 188 & - & - & 34 & 16 & 32 \\
\hline Predgomae & - & 63 & - & 31 & 63 & 63 & - & 16 & - & 16 & - & 83 & - & - & - & - & - & 125 & + & - & - & $\cdot$ & - & - & - & - & - & 6 \\
\hline Qing네퓨 & 47 & 31 & - & 31 & 63 & 63 & 63 & 148 & - & 55 & - & 63 & - & - & 31 & 63 & 63 & 94 & - & - & = & 31 & $18 \mathrm{~g}$ & - & - & 31 & 16 & 10 \\
\hline Rubir:owce Duki. & - & 31 & 31 & 53 & . & 125 & - & 16 & - & 78 & - & - & 63 & 31 & 63 & 1.25 & - & $=$ & 31 & - & - & - & - & B3 & - & - & 39 & $B$ \\
\hline Sanse & 23 & 31 & 16 & 47 & 31 & 94 & 31 & 82 & - & 68 & - & 31 & 31 & 16 & $4 \overline{7}$ & 94 & 31 & 47 & 16 & 16 & 15 & 16 & 94 & 31 & - & 16 & 27 & 5 \\
\hline Scarlet & - & 78 & 16 & 63 & 63 & 125 & - & 23 & - & 55 & + & 63 & 31 & 16 & 31 & 63 & - & 125 & 16 & - & - & - & - & 31 & - & - & 20 & 0 \\
\hline Serishu & 23 & 31 & - & 23 & 47 & 47 & 31 & 70 & - & 31 & - & 47 & - & - & 16 & 31 & 31 & 78 & - & - & - & 16 & 94 & - & - & 16 & 8 & 24 \\
\hline Shamrock & 47 & 31 & 47 & 16 & 156 & 31 & 94 & 141 & 63 & 47 & 63 & 156 & 125 & 141 & 47 & 63 & 94 & 94 & 15 & $=$ & - & $7 a$ & 188 & 125 & 39 & 47 & 47 & 3 \\
\hline Skifgkoe & 47 & - & - & 16 & 37 & 31 & 63 & 141 & - & 47 & - & 31 & r & - & 31 & 63 & 63 & 31 & - & - & - & 31 & 186 & - & - & 31 & 16 & 32 \\
\hline Summerdel & - & 53 & - & 31 & 53 & 63 & . & 16 & - & 16 & - & 63 & - & $=$ & - & - & - & 125 & - & $=$ & - & $=$ & - & - & - &. & - & 16 \\
\hline Sundowner & 47 & - & - & 16 & 31 & 31 & 63 & 141 & - & 47 & . & 31 & - & - & 31 & 63 & 63 & 31 & - & - & - & 34 & 188 & - & - & 31 & 16 & 32 \\
\hline Suntan & - & - & - & - & - & - & - & - & - & - & - & - & - & - & - & - & - & - & - & 63 & 63 & - & - & - & - & . & - & 5 \\
\hline Vista Bella & - & 35 & 59 & - & 47 & - & 12 & + & 23 & - & 23 & 47 & 47 & 66 & 20 & - & 39 & 23 & 20 & - & - & 55 & r & 47 & 12 & 20 & 93 & 25 \\
\hline Yanshanhong & - & 83 & - & 31 & 63 & 63 & - & 16 & - & 16 & - & 63 & - & - & - & - & - & 125 & - & - & - & - & - & - & - & - & - & 16 \\
\hline Itan & 25 & 29 & 14 & 31 & 45 & 61 & 36 & 76 & 6 & 45 & 9 & 45 & 26 & 21 & 31 & 58 & 35 & 57 & 9 & 7 & 7 & 21 & 92 & 26 & 3 & 20 & 23 & 32 \\
\hline
\end{tabular}

${ }^{\mathrm{z} C o e f f i c i e n t s ~ o f ~ c o a n c e s t r y ~ v a l u e s ~} \times 1000$; self-pollinated $=500 ;$ parent-offspring $=250 ;$ full sibs $=250 ;$ half sibs $=125 ;$ first cousins $=63$. No coancestry of known parents indicated with dashes.

${ }^{\mathrm{y}}$ Cultivars with incomplete parentage.

list 35. HortScience 26:951-978.

Brooks, R.M. and H.P. Olmo. 1994. Register of new fruit and nut varieties list 35. HortScience 29:942-969.

Brown, A.G. 1973. The effect of inbreeding on vigour and length of juvenile period in apples. Proc. Eucarpia fruit section Symp. V. Top fruit breeding. Canterbury, England, 11-14 Sept. 1973. p. 30-39.

Brown, S.K. 1992. Genetics of apple. Plant Breeding Rev. 9:333-366.

Byrne, D.H. 1989. Inbreeding, coancestry, and founding clones of Japanese-type plums of California and the southeastern United States. J. Amer. Soc. Hort. Sci. 114:699-705.

de Coster, J. 1986. New apple cultivars. Compact Fruit Trees 19:144-158. Cripps, J.E.L., L.A. Richards, and A.M. Mairata. 1993. 'Pink Lady' apple. HortScience 28:1057.

Crosby, J.A., J. Janick, P.C. Pecknold, S.S. Korban, P.A. O’Connor, S.M.
Ries, J. Goffreda, and A. Voordeckers. 1992. Breeding apples for scab resistance: 1945-1990. Fruit Var. J. 46:145-166.

Cruden, D. 1949. The computation of inbreeding coefficients. J. Hered. 40:248-251.

Dale, A., P.P. Moore, R.J. McNicol, T.M. Sjulin, and L.A. Burmistrov. 1993. Genetic diversity of red raspberry varieties throughout the world. J. Amer. Soc. Hort. Sci. 118:119-129.

Davis, M.B., D.S. Blair, and L.P.S. Spangelo. 1954. Apple breeding at the Central Experimental Farm, Ottawa, Canada, 1920-1951. Proc. Amer. Soc. Hort. Sci. 63:243-250.

Dayton, D.F., J.B. Mowry, E.B. Williams, J. Janick, F.H. Emerson, L.F. Hough, and C.H. Bailey. 1977. Co-op 19, 20, 21, and 22: Four scabresistant apple selections released for advanced testing. Purdue Univ. Agr. Expt. Sta. Bul. 755. 
Fischer, C. and M. Fischer. 1993a. Summer apple variety 'Retina'. Erwerbsobstbau 35:79.

Fischer, C. and M. Fischer. 1993b. Winter apple variety 'Rewena'. Erwerbsobstbau 35:80.

Gradziel, T.M., W. Beres, and K. Pelletreau. 1993. Inbreeding in California canning clingstone peach cultivars. Fruit Var. J. 47:160-168.

Hancock, J.F. and J.H. Siefker. 1982. Levels of inbreeding in highbush blueberry cultivars. HortScience 17:363-366.

Korban, S.S., P.A. O'Connor, S.M. Ries, J.A. Janick, J.A. Crosby, and P.C. Pecknold. 1990. Co-op 27, 28, 29, 30, and 31: Five disease-resistant apple selections released for advanced testing. Ill. Agr. Expt. Sta. Bul. 789.

Lantz, H.L. 1936. Apple breeding: An example of parental prepotency in two progenies of the Delicious apple. Proc. Amer. Soc. Hort. Sci. 33:10 12.

Le Lezec, M. and J. Babin. 1992. Pommier. Variétés incrites en 1992. Catalogue officiel des espèces et variétés fruitières. Arboricult. Fruitière 453:18-20.

Lesley, J.W. 1957. A genetic study of inbreeding and of crossing inbred lines of peaches. Proc. Amer. Soc. Hort. Sci. 70:93-103.

Lindgren, D., L.D. Gea, and P.A. Jefferson. 1995. Status number-A measure of genetic diversity. Evolution of breeding strategies for conifers from the Pacific North West. Proc. joint meeting IUFRO working parties S2.02.05;06.12 and .14. Limoges, France, 28 July-4 Aug. 1995.

Malécot, G. 1948. Les mathématiques de l'hérédité. Masson \& Cie, Paris.

Noiton, D. and C.G.A. Shelbourne. 1992. Quantitative genetics in an apple breeding strategy. Euphytica 60:213-219.

Parisi, L., Y. Lespinasse, J. Guillaumes, and J. Krüger. 1993. A new race of Venturia inaequalis virulent to apples with resistance due to the $V f$ gene. Phytopathology 83:533-537.

Percival, D.C. and T.A. Proctor. 1994. 'Golden Delicious' progeny: 21st century apples. Fruit Var. J. 48:58-62.

Roach, F.A. 1985. History and evolution of fruit crops. HortScience
23:51-55.

Sadamori, S., Y. Yoshida, S. Tsuchiya, T. Haniuda, H. Murakami, H. Suzuki, and S. Ishizuka. 1973. New apple variety 'Akane'. Bul. Hort. Res. Sta., Japan, Ser. C No 8.

Sansavini, S. 1993. Il miglioramento genetico del melo per la resistenza alle avversita biotiche. Riv. Frutticult. 5:61-73.

Scorza, R., S.A. Mehlenbacher, and G.W. Lightner. 1985. Inbreeding and coancestry of freestone peach cultivars of the eastern United States and implications for peach germplasm improvement. J. Amer. Soc. Hort. Sci. 110:547-552.

Scorza, R., W.B. Sherman, and G.W. Lightner. 1988. Inbreeding and coancestry of low chill short fruit development period freestone peaches and nectarines produced by the University of Florida breeding program. Fruit Var. J. 42:79-85.

Smith, M.W.G. 1971. The national apple register of the United Kingdom. Min. of Agr., Fisheries, and Food, London.

Tamba, J., S. Tanno, and H. Sato. 1992. New apple cultivar 'Akita Gold'. J. Jpn. Soc. Hort. Sci. 61(Suppl.2):110-111.

Wang, Y.L. 1990. Apple breeding in China. Plant Breeding Abstr. 60:1315-1318.

Way, R.D., H.S. Aldwinckle, R.C. Lamb, A. Rejman, S. Sansavini, T. Shen, R. Watkins,

M.N. Westwood, and Y. Yoshida. 1990. Apples. Acta Hort. 290. 1-62.

Williams, E.B., J. Janick, and F.H. Emerson. 1967. Five scab-resistant apple selections released for grower testing. Purdue Univ. Agr. Expt Sta. Bul. 271.

Williams, E.B., J. Janick, and F.H. Emerson. 1975. Co-op 12-18: Seven scab-resistant apple selections released for advance testing. Purdue Univ. Agr. Expt Sta. Bul. 69.

Williams, E.B., J. Janick, F.H. Emerson, S.S. Korban, and D.F. Dayton. 1984. Co-op 23, 24, 25, and 26: Four scab-resistant apple selections released for advanced testing. Purdue Univ. Agr. Expt Sta. Bul. 456.

Yamada, M., C. Suzuki, and M. Ishiyama. 1980. New apple variety 'Tsugaru'. Bul. Aomori Apple Expt. Sta. 18:1-10. 